\title{
Secondary minerals in the geyserites of the Geysers Valley (Kamchatka)
}

\author{
Anastasia Sergeeva ${ }^{1}$, and Alexey Kiryukhin ${ }^{1, *}$ \\ ${ }^{1}$ Institute of Volcanology and Seismology, Far Eastern Branch of the Russian Academy of \\ Sciences, Petropavlovsk-Kamchatsky, Piip 9, Russia 683006
}

\begin{abstract}
Secondary minerals assemblages that are deposited from thermal solutions at the top of geysers (Velikan, Bolshoy) were investigated. It is established that assemblages are represented mainly by opal and highsilica zeolites (mordenite and heulandite). As conditions of feeding hydrothermal reservoir change, minerals of the kaolinite group and smectites may appear.
\end{abstract}

\section{Introduction}

Geysers are unique natural objects characterized by cyclic eruptions of a gaswater mixture. Most of geysers in Kamchatka are located in the Geysers Valley, Kronotsky Reserve [1].

The secondary mineral assemblages that form the geyser structures (geyser dome) are a reflection of a complex processes, including the interaction of geothermal fluids with host rocks, meteoric waters, fluid phase separation, and etc. In this regard, the study of mineral assemblages of geyserite deposits (sinter) is relevant both from the point of view of fluid behavior on the evaporation barrier, and from view of describing the mineral forming processes that are realized in the specific conditions of active thermal anomalies.

The sinter's content is sensitive to the composition of the solution from which it is formed, therefore its study allows to track the geofluds dynamics in parent geothermal reservoirs.

\section{Experimental technique}

Silicon coatings that were formed on loggers (T-logger used for long-term monitoring of geysers cycling $[1,4,5])$ in geysers Bolshoy, Velikan were investigated. Samples were taken during the period of 2011-2018. The study of the mineral composition was carried out using the methods of infrared spectroscopy and X-ray dif-

Corresponding author: AVKiryukhin2@mail.ru 
fractometry.

The IR absorption spectra were recorded on an IR Affinity infrared spectrophotometer (Shimadzu), in the range of wave numbers $400-4000 \mathrm{~cm}^{-1}$, with a resolution of $4 \mathrm{~cm}^{-1}$. Air-dry samples were ground with potassium bromide and pressed into tablets.

The X-ray patterns were obtained using an XRD 7000 X-ray diffractometer (Shimadzu) in the range of angles $\left(6-60^{\circ}\right)$ with the step $0.1^{\circ}$ and scanning speed -1 $\mathrm{deg} / \mathrm{min}$. The scanning speed is equivalent to the expose at a point within 3 seconds.

The X-ray diffraction patterns were identified by using the Powder-Cell program, where the experimental and theoretical curves were compared. The specification of the profile parameters was performed using the built-in algorithm that implements the Rietveld method.

\section{Results}

The figure 1 shows an example of the Velikan sinter raincoat with drilled samples to determine the mineral composition. The figures 2 and 3 demonstrate the IR spectra of the samples.

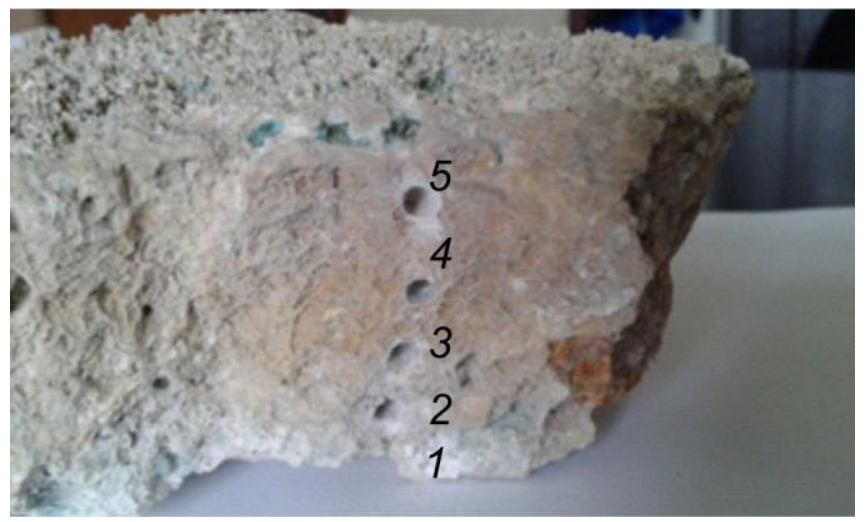

Fig. 1. The sample of the Velican's sinter raincoat with drilled holes for sampling, numbering from bottom to top.

The main absorption bands refer to opal, amorphous hydrated $\mathrm{SiO}_{2}$. In the high frequency area (3000-4000 $\left.\mathrm{cm}^{-1}\right)$, in which the vibrations of water molecules and $\mathrm{OH}$ groups are located, there is a broad intense absorption band. When the band is decomposed into Gaussian components, several peaks are allocated, some of which correspond to water molecules in opal, the other part refers to water coordinated in the structure of zeolites (Fig. 3).

In the area of 900-1200 $\mathrm{cm}^{-1}$ is located the main absorption band of the siliconoxygen skeleton. On the X-ray patterns were identified opal, quartz, heulandite, and mordenite. The newly formed minerals of the geyserite raincoat were poorly crystallized; the X-ray patterns are very blurred, with the halo from amorphous opal. It can be noted that the intensity of the absorption bands of zeolites increases in the direction to the upper part of the geyserite raincoat.

Deposits containing kaolinite group minerals were formed on the loggers surface 
in the Velikan geyser (Fig. 4) in 2011 and 2018: kaolinite (2018) and kaolinite with dickite (2011). The profile of the absorption spectrum in the area of $900-950 \mathrm{~cm}^{-1}$ on curves 1 (Fig. 4) probably corresponds to dickite [2]. It should be noted that in the deposits of 2018 the amount of the kaolinite group minerals sharply decreases, and dickite disappears but the content of zeolites increases.

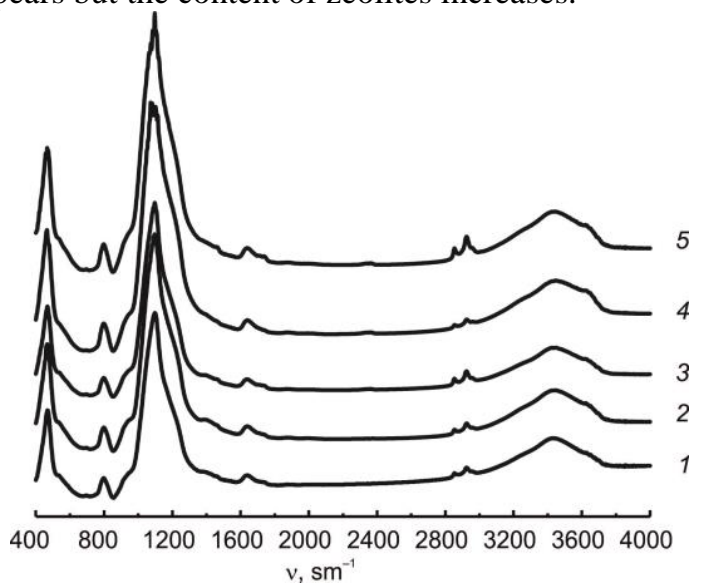

Fig. 2. Infrared spectra of the Velikans geyserite raincoat. From the bottom of the raincoat (1) to the outer surface (5).
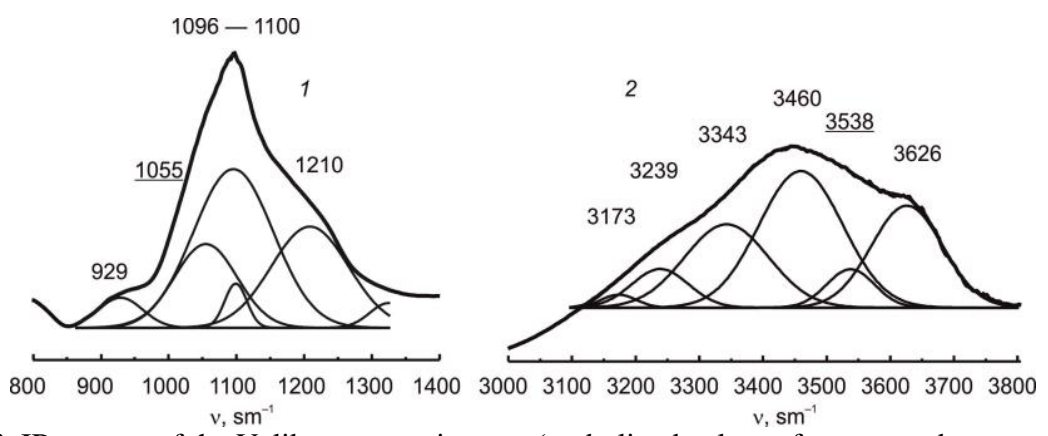

Fig. 3. IR spectra of the Velikans geyserite coat (underlined values of wave numbers correspond to zeolite bands). Decomposition of the main absorption band $\left[\mathrm{SiO}_{2}\right](1)$ and the highfrequency absorption band of water molecules (2).

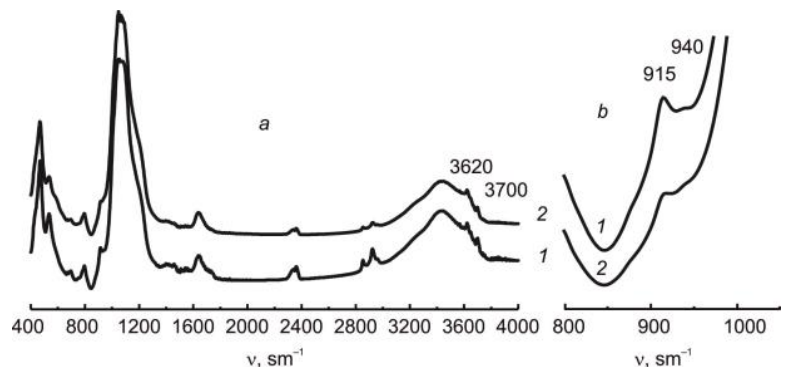

Fig. 4. Infrared spectra of sediments in the range of $400-4000 \mathrm{~cm}^{-1}$ (a) and $800-1050 \mathrm{~cm}^{-1}$ (b) on the Velikan geyser loggers formed in 2011 (1) and 2018 (2). 


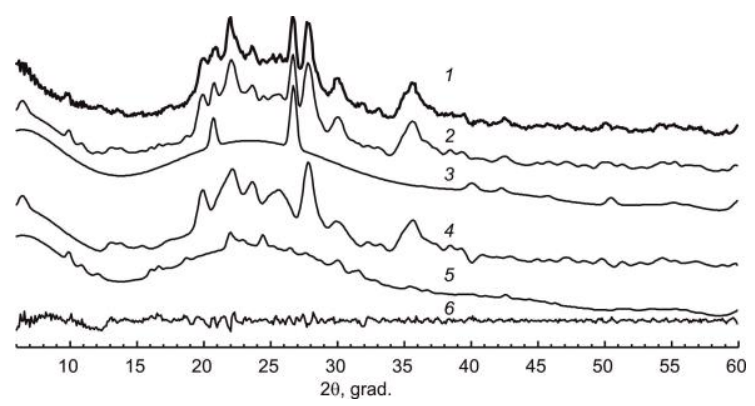

Fig. 5. Experimental (1) and theoretical (2) X-ray patterns of the Velican loggers deposits, 2018. Theoretical pattern is the sum of refined curves of quartz and opal (3), mordenite (4), heulandite (5), difference of theoretical and experimental curves (6).

Similarly, deposits on the Bolshoy geyser loggers were studied, which were formed in 2011 and $2018 \mathrm{yr}$. In $2011 \mathrm{yr}$ were identified opal, quartz, newly formed kaolinite, Fe-smectite, zeolites were founded in trace amounts. But in $2018 \mathrm{yr}$ the minerals composition has changed significantly. The contents of opal, high-siliceous zeolites (mordenite, heulandite) increased, but kaolinite and smectite disappeared.

\section{Discussion of results}

Secondary minerals deposited on the loggers surfaces of both geysers in $2011 \mathrm{yr}$. correspond to a solution with a $\mathrm{pH}$ close to neutral or slightly acidic. After seven years (2018), the composition of the mineral assemblages has changed. The minerals of the kaolinite group disappeared, whereas the content of zeolites increased. It means the assemblage of secondary minerals corresponds to an alkaline medium. It should be noted that the formation of geyserite occurs during dozens of years; deposits on loggers are formed for several months. Therefore, a large-scale reconstruction of the mineral formation is possible studying the composition of geyseritic raincoats. The geyserite raincoat of the Velikan geyser has a variable content of zeolites, that means $\mathrm{pH}$ of the solution is changeable. At the beginning of the rain coat formation, $\mathrm{pH}$ was around $7-8$ or slightly lower. At the end of this process, during the formation upper part raincoat, $\mathrm{pH}$ was 9.3.

The waters composition of studied geysers, is given in [1]. The sodium content ranges from 600 to $800 \mathrm{mg} / \mathrm{l}$, calcium 20 to $60 \mathrm{mg} / \mathrm{l}$, dissolved silica up to $1 \mathrm{~g} / \mathrm{l}$. These solutions correspond to compositions coexisting with high-silicon zeolites [3]. In works on the synthesis of zeolites [3], were shown that the rate of their generation increases in alkaline media, while opal generated in weakly acidic solutions

Layered silicates - kaolinite and smectite, are formed in solutions with a $\mathrm{pH}$ close to neutral or lower. $\mathrm{pH}$ measurements of discharging waters from the geysers in 2018 show an alkaline environment, more than 9.3 Increasing $\mathrm{pH}$ of thermal waters due to mixing with meteoric waters leads to the disappearance of smectite and kaolinite from deposits, they replaced by zeolites.

The $\mathrm{pH}$ values in the solutions of geysers are due to the hydrolysis of carbonate ions. Sodium cations are predominant over calcium and magnesium cations in solution. Under these conditions, by heating and lowering the partial pressure of $\mathrm{CO}_{2}$ in the solution, highly soluble sodium carbonate is formed. Its hydrolysis increases the $\mathrm{pH}$ of the solution up to 9 - 10, depending on sodium concentration. In turn, the al- 
kaline environment promotes the generation of zeolites, and an opal-zeolite assemblage is formed. If calcium and magnesium are predominated in the solution, carbonates would be precipitated from the solution (calcite and others).

At the same time, the carbonate ion is responsible for the hydrolysis and $\mathrm{pH}$ was bound and left the solution. As a result, a significant increase in $\mathrm{pH}$ does not occur and a carbonate-opal association would form at the geysers domes.

\section{Conclusion}

Deposits of the geysers domes consist mostly from opal and high-silica zeolites (heulandite, mordenite). The formation of zeolites at the geysers domes is determined by two factors: an alkaline medium $(\mathrm{pH}>9.3)$ and the predominance of sodium over calcium in the thermal water. Lower $\mathrm{pH}$ in the past period corresponds to decrease in the content of zeolites in sinter and the formation of an opal-kaolinite assemblage. Higher $\mathrm{pH}$ values and an alkaline medium in the current conditions corresponds to increase of the rate of zeolites formation.

This work was supported by the grant of the Russian Foundation for Basic Research, project No. 18-05-00052.

\section{References}

1. A.V. Kiryukhin, T.V. Rychkova, I.K. Dubrovskaya. Formation of the hydrothermal system in Geysers Valley (Kronotsky Nature Reserve, Kamchatka) and triggers of the Giant Landslide // Applied Geochemistry. 27. 1753-1766 (2012)

2. N.V. Chukanov. Infrared spectra of mineral species. Extended library. Springer Geochemistry/Mineralogy. 1, 1726 (2014)

3. S.P. Zhdanov, S.S. Khvoschev, N.N. Samulevich. Synthetic zeolites. M.: Chemistry. 264 (1981)

4. A. Kiryukhin. Modeling and observations of geyser activity in relation to catastrophic landslides-mudflows (Kronotsky nature reserve, Kamchatka, Russia). Journal of Volcanology and Geothermal Research, 323, 129-147 (2016)

5. A. Kiryukhin, V. Sugrobov, E. Sonnenthal. Geysers Valley $\mathrm{CO}_{2}$ Cycling geological Engine (Kamchatka, Russia) // Geofluids Journal, 17 (2018) https://www.hindawi.com/journals/geofluids/aip/1963618/ 